\section{Transformational leadership, social capital and organizational innovation}

Social capital and organizational innovation

\author{
Lu Chen
}

School of Economics and Management, University of Electronic Science and Technology of China, Chengdu, China

Wei Zheng Department of Management and Marketing, University of Wisconsin - River Falls, River Falls, Wisconsin, USA

Baiyin Yang

School of Economics and Management, Tsinghua University, Beijing, China, and

Shuaijiao Bai

School of Economics and Management, University of Electronic Science and Technology of China, Chengdu, China

\section{3}

Revised 29 January 2016 14 April 2016

Accepted 14 April 2016
Received 22 July 2015

\begin{abstract}
Purpose - The purpose of this paper is to investigate the forces driving organizational innovation, particularly CEO transformational leadership as it affects external and internal social capital in top management teams.

Design/methodology/approach - Survey questionnaires were administered to 90 Chinese top management teams. Structural equation modeling was used to test the hypothesized relationships.

Findings - Both internal and external social capital mediated the relationship between transformational leadership and organizational innovation.

Practical implications - Organizations should strengthen internal and external capital of top management teams to reap maximal innovation outcomes from transformational leadership.

Originality/value - The findings contribute to the transformational leadership, social capital, and innovation literature first by showing how leadership influences innovation through largely neglected mechanisms - internal and external social capital. Second, a social capital focus challenges the tacit assumption that transformational leadership has only internal influences by showing that it potentially spills over to the external domain.
\end{abstract}

Keywords Transformational leadership, Organizational innovation, Social capital,

Top management team

Paper type Research paper

(C) Chen, Zheng, Yang and Bai. Published by Emerald Group Publishing Limited. This article is published under the Creative Commons Attribution (CC BY 3.0) licence. Anyone may reproduce, distribute, translate and create derivative works of this article (for both commercial and non-commercial purposes), subject to full attribution to the original publication and authors. The full terms of this licence may be seen at http://creativecommons.org/licences/by/3.0/legalcode.

This project is supported by National Science Foundation of China (No. 71102053 \& No. 71472024) and the Major Program of National Natural Science Foundation of China (No. 71232002). The authors thank Paul Humphreys and two anonymous reviewers for their helpful comments. The authors are also grateful to Yuemei Wang for research assistance work. 
LODJ

37,7

844

\section{Introduction}

Transformational leadership (hereafter, TFL) is a key predictor for organizational innovation (Mumford et al., 2002). Possible mediators between TFL and innovation have been identified, including psychological empowerment, perceived support for innovation (Gumusluoglu and Ilsev, 2009; Jung et al., 2008; Sarros et al., 2008), organizational learning (García-Morales et al., 2012), and resources and policies (Oke et al., 2009). Although the list provides a beginning for illuminating the paths of influence TFL exerts on innovative outcomes, considerable gaps exist. A meta-analysis of 25 years of research on the impact of TFL on organizational outcomes prompted Wang et al. (2011) to call for further investigation of the mediators of TFL.

TFL impact studies have predominantly focussed on human capital (Birasnav et al., 2011; Peachey et al., 2014) rather than on social capital. Human capital comprises individual resources, whereas social capital encompasses relational resources that facilitate action and create value (Adler and Kwon, 2002). Both human and social capital resources are essential for competitive advantage (Barney, 1991, 2001; Coff, 1997; Dess and Sauerwald, 2014). An important human capital resource that significantly impacts organizational performance is leadership (Wright et al., 2001) but it does not occur in isolation (O'Reilly et al., 2010). Instead, leadership is embedded in the rarely examined relational context (Bono and Anderson, 2005; Zhen and Peterson, 2011). Social capital theory suggests that social relationships among organizational members and with outside actors confer vital resources such as information, advice, social support, and friendship (Burt, 1997), all important preconditions for information sharing, knowledge creation, risk-taking, and innovation (Zhen and Peterson, 2011). Therefore, leaders manage and influence a vital part of organizational resources through social capital (Hitt and Ireland, 2002), but only a few studies have addressed the effects of TFL on social capital (Bono and Anderson, 2005). Although social capital plays an important role in enhancing innovation (Eklinder-Frick et al., 2014), both leadership and social capital research has somewhat neglected to study how transformational leaders leverage social capital to foster innovation.

A social capital perspective takes us beyond organizational confines to capture internal group "bonding" (collaboration, cooperation, and trust) and external "bridging" linkages (Adler and Kwon, 2002). Exploring social capital as a mediator addresses another literature gap that limits TFL impacts to intra-organizational boundaries (Flynn and Staw, 2004). Transformational leaders must scan the environment to discover and establish extensive internal and external exposures to diverse viewpoints (Heavey et al., 2009). Transformational leaders become role models for spanning boundaries and proactively reaching outside actors to exchange information, foster inter-organizational collaboration, forge coalitions, and leverage resources (Den Hartog and Belschak, 2012). Therefore, TFL may strongly encourage followers to form external social capital that creates and sustains competitive advantages (Carter et al., 2015).

In the present study, the authors address both gaps in the literature and examine how transformational leaders foster innovation by managing resources embedded in social relations among organizational members. The authors focus on upper echelons (CEOs and their top management teams; hereafter, TMT) because they have the ultimate responsibility to set strategic directions, make strategic decisions, and create organizational cultures that foster or inhibit innovation (Kang et al., 2015). Consequently, this study explores TMT relationships with external entities for bringing value and innovation possibilities. 
In this study, strategic management literature, leadership literature, and social capital literature are combined for better understanding of how TFL influences innovation. By showing how leaders leverage resources embedded in social relations for innovation purposes, the authors address a literature gap and respond to the call for discovering how TFL influences organizational performance (Wang et al., 2011). More specifically, the literature on TFL and innovation links has focussed on mediators such as supportive climate and organizational structure (e.g. Gumusluoglu and Ilsev, 2009; Jung et al., 2008; Sarros et al., 2008). This study adds a new perspective by exploring an important but largely neglected leverage point for leadership in the pursuit of innovation - social capital as it relates to organizational behavior and strategic management. Furthermore, the study challenges tacit assumptions that TFL has only internal influence. Instead, using a social capital lens reveals potential spillover to the external domain. Expanding the scope adds to the TFL literature and potentially informs managerial practices by clarifying how TFL can provide internal and external capital for maximizing innovation.

\section{Theoretical background and hypotheses}

The resource-based view provides our theoretical backdrop (Barney, 1991, 2001). According to the resource-based view, organizations can sustain competitive advantages by exploiting environmental opportunities and neutralizing threats by utilizing valuable, rare, imperfectly imitable, and non-substitutable resources such as human capital (Coff, 1997) and social capital (Dess and Sauerwald, 2014). Accessing and using employees' knowledge, skills, and abilities creates economic value (Barney, 1991). An important human capital resource related to organizational performance is leadership (Wright et al., 2001). Social capital resides between individuals; encompasses trust, cohesion, access to information and resources, exposure to new knowledge, and learning; and enables organizations to develop or implement multiple strategies that improve efficiency and effectiveness (Adler and Kwon, 2002; Nahapiet and Ghoshal, 1998). The resource-based view reveals how human capital and social capital interrelate to create competitive edge.

\section{CEO TFL and TMT social capital}

Top managers are said to have TMT social capital when their social relationships with team members and external actors convey goodwill and benefits such as information, resources, and solidarity (Shipliov and Danis, 2006). Internal social capital (hereafter, ISC) comes from within-group bonding ties; external social capital (hereafter, ESC) comes from bridging out-group ties (Adler and Kwon, 2002). CEOs who display TFL are expected to affect levels and quality of both ISC and ESC in their TMTs.

\section{TFL and ISC}

TMT members demonstrate ISC by sharing collective linkages (Adler and Kwon, 2002). ISC includes trust, information sharing, and shared vision (Leana and Pil, 2006). First, transformational leaders build trust and cooperation relationships among TMT members (Schaubroeck et al., 2011). Transformational leaders serve as admired, trusted, and respected role models who inspire idealized influence behavior according to high ethical and moral standards (Bono and Anderson, 2005). Furthermore, by showing individualized consideration for team members, transformational leaders enhance justice perceptions regarding the leader and the organization, which cultivates horizontal trustful relationships among team members (Cho and Dansereau, 2010). 
LODJ

37,7

846

Second, transformational leaders usually inspire their TMTs to share a great deal of information sharing (Carmeli et al., 2013). Transformational leaders are usually charismatic and tend to occupy central positions in internal advice and influence networks (Bono and Anderson, 2005; Balkundi et al., 2011) so that they are directly connected with almost all team members for transmitting goals, anticipating problems, soliciting advice, and managing the flow of resources (Sauer and Kauffeld, 2015). Furthermore, they provide intellectual simulation for establishing TMT cooperative norms and open communication, which in turn leads to greater information sharing (Tjosvold et al., 2009).

Finally, transformational leaders shape and consolidate enthusiastic visions for the future among TMT members (Jansen et al., 2008) regarding strategic directions and ideas (Bono and Anderson, 2005), energizing them to fully embrace meaning, challenges, and collective objectives beyond their own interests. Members are therefore encouraged to focus on accomplishing common goals and shared visions (Gupta et al., 2011). Thus:

H1a. TFL is positively related to the TMT's ISC reflected in trust, shared information, and shared vision.

\section{TFL and ESC}

TMT members who have ESC will have relational interactions and networks of relationships with external entities that hold information of potential value to the organization (Shipliov and Danis, 2006). To the authors' knowledge, relationships between CEO's TFL and TMT's ESC have not been directly tested but the literature has provided some grounds for connecting TFL and ESC.

First, transformational leaders model boundary-spanning behavior: scanning the environment, interacting with external entities (Heavey et al., 2009), absorbing information and insights, and identifying options for choosing strategic directions (Glaser et al., 2015). Their inspirational motivation and idealized behaviors then incentivize TMT members to build external networks and sharpen their boundary-spanning abilities. Consequently, they generate high quality ESC by being strongly motivated to scan information across organizational boundaries, take risks, be experimental, and develop external connections and resources (Briona et al., 2012).

Second, CEOs occupy "linking-pin" positions connecting their TMT members with organizational outsiders. By virtue of their formal roles and charisma, transformational leaders have legitimacy and access to influential people and resources beyond their followers' reach (Sparrowe and Liden, 2005) and thus may be optimally positioned to obtain outside political support such as from government agencies and outside cooperation such as from suppliers and customers (Sarin and McDermott, 2003). Transformational leaders' reputation and prestige then gives TMT members outside legitimacy and trustworthiness, and increases their opportunities to build valuable social ties and extract their value (Burt, 1997). Social capital leads to positive externalities; that is, leaders' social networks benefit both their own success and spills over to benefit their subordinates (Galunic et al., 2012). Moreover, TMT members are more likely to meet powerful people through their leaders' network of accumulated social capital (Bono and Anderson, 2005). In summary, TFL can facilitate TMT members' boundary-spanning behaviors, which leads to higher ESC. Thus:

H1b. TFL is positively related to TMTs' ESC. 
ISC and ESC as mediators of the relationship between TFL and organizational innovation Organizational innovation is defined as the creation of valuable and useful new products/services, and more efficient and adaptive administrative mechanisms that support product/service innovation (Kang et al., 2015). The direct relationships between CEOs' TFL and organizational innovation have been empirically well-supported (García-Morales et al., 2012; Gumusluoglu and Ilsev, 2009; Jung et al., 2008). In this study, ISC and ESC are explored as mediators of the relationship between TFL and organizational innovation.

Although social capital is known to facilitate innovation through enhanced ability to collect and manage multiple information sources (Bono and Anderson, 2005; Houghton et al., 2009), to the authors' knowledge, researchers have failed to investigate social capital as a mediator of TFL - innovation associations at upper-echelon levels. Nevertheless, as indicated, evidence is growing for a linkage between TFL and both types of social capital at the TMT level, as well as the potential mediating effects of ISC and ESC on competitive advantages related to CEO leadership behavior (Hitt and Ireland, 2002). Next the authors weigh arguments from both leadership and social capital perspectives in support of the hypotheses.

The mediating role of ISC

CEOs who display TFL accelerate organizational innovation by encouraging information sharing, cultivating trust, and fostering shared vision among TMT members. First, transformational leaders develop close emotional ties and higher levels of trust with team members who can then trust one another's intentions regarding decisions and implementation during times of uncertainty and vulnerability. They will be less fearful of taking risks in creating new knowledge and will be more likely to have interactions and exchanges that may lead to discovering greater novelty and enhanced innovation (Sanchez-Famoso et al., 2014). Second, transformational leaders are able to facilitate team member interactions, build strong relationships, and establish norms of information sharing for enhanced collaboration and mutual responsibility (Sparrowe et al., 2001). Organizations that share information well are more likely to possess unique and rare knowledge that is difficult for rivals to replicate, resulting in effective organizational innovativeness (Lin, 2007). Finally, transformational leaders articulate appealing and evocative visions that inspire followers to feel additional goal-directed energy. Shared vision creates a sense of shared responsibility and collective action (Nahapiet and Ghoshal, 1998), team potency, teamwork, and altruistic team behavior, all critical to innovation (Pearce and Ensley, 2004). Combining those arguments, transformational leaders facilitate information sharing, trust, and shared vision in TMTs. Enhanced ISC, in turn, increases the potential for strong innovativeness in the entire organization (Sanchez-Famoso et al., 2014). Thus:

H2a. TMT's ISC mediates the relationship between TFL and organizational innovation.

\section{The mediating role of ESC}

To reiterate, TFL encourages spanning behaviors which yield higher quality ESC. ESC then bridges organizations with outside stakeholders (Adler and Kwon, 2002) and provides information exchange, access to resources, and collaborative opportunities. First, executives' social ties with external actors (such as with customers, business partners, suppliers, distributors, and public service providers) can expose organizations 
LODJ

37,7

848

to more diverse information channels, expand breadth of perspectives, increase abilities to harness available information, and enhance the creation of novel ideas (Adler and Kwon, 2002; Burt, 1997). Transformational leaders are role models of environmental scanning and boundary spanning (Heavey et al., 2009), which then motivates TMT members to pursue connections with diverse channels and perspectives that foster idea creation. Second, external ties give access to outside resources that can trigger opportunities to create new knowledge and products (Nonaka, 1991), acquire alliance resources (Koka and Prescott, 2002), and secure legitimacy for new initiatives (Tushman and Murmann, 1998). As transformational leaders are more adept at obtaining trust and legitimacy from outsiders (Sparrowe and Liden, 2005), they can help their TMT members access the alliance resources and external support that are essential to innovation. In summary, TFL can facilitate boundary-spanning behaviors of TMT members, leading to higher ESC and enhancing innovation (Li et al., 2013). Thus:

$H 2 b$. TMT's ESC mediates the relationship between TFL and organizational innovation.

\section{Methods}

\section{Sample and procedure}

Survey questionnaires were distributed to companies operating in Chengdu Modern Industrial Park, a major platform for technology and service industry development and innovation supported by the local government of Chengdu, China. Companies selected for the study were required to be at least three-years-old and to rely on product innovation for company survival. Using a list of contact information for CEOs of 167 target companies that satisfied the criteria, the first author called the CEOs, introduced the objective and design of the study, and asked for approval for the field investigation. Next, the first author visited CEOs of the 90 firms that agreed to participate and asked each to name the key members of their TMTs and a middle-level finance manager outside the TMT. The finance manager was surveyed to provide separate evaluation of innovation performance. He/she had to be at mid-management level, in charge of accounting and finance, have at least three years of experience with the company, and be familiar with the firm's performance in the past three years. All respondents were guaranteed confidentiality and anonymity. Respondents received the questionnaires in envelopes and were told to seal their completed forms. Questionnaires were collected immediately after completion on site. Overall, usable questionnaires were obtained from 90 firms, a response rate of 56.3 percent.

The average team in the 90 firms had 5.25 executives, including the CEO; the largest team had eight and the smallest team had three. A total of 206 TMT members completed and returned the questionnaires (an average of one CEO and 2.29 members per firm). The companies in the sample operated in diverse industries, including electronic components, software development, manufacturing, food and beverages, energy, pharmaceuticals, and environment protection. Participating and non-participating companies showed no significant differences in terms of size as measured by number of employees $(p>0.10)$.

\section{Measures}

To minimize common method bias, data were collected from multiple sources in different formats: CEOs of each surveyed company provided information on their personal and TMT demographic characteristics and ISC and ESC of their TMTs; TMT members (excluding the CEO) provided data on the CEO's TFL behaviors; and financial managers provided data regarding company context and innovation performance. 
TFL. TFL was measured using the 16-item scale from Bass and Avolio's (1997) Multifactor Leadership Questionnaire. For example: "My CEO gets me to look at tasks from many different angles." The confirmatory factor analyses (CFA) results showed that the original measurement model of TFL is not a good fit to the data $\left(\chi^{2}=197.87\right.$, $\mathrm{df}=104, \mathrm{CFI}=0.82, \mathrm{TLI}=0.80, \mathrm{SRMR}=0.08, \mathrm{RMSEA}=0.08$ ). After excluding three items with lower factor loadings[1], the first-order one-factor model of TFL exhibits an acceptable fit to the data $\left(\chi^{2}=78.24, \mathrm{df}=63, \mathrm{CFI}=0.97, \mathrm{TLI}=0.97, \mathrm{SRMR}=0.05\right.$, RMSEA $=0.04$ ). Furthermore, CFA was conducted to compare the first-order one-factor model of TFL with the second-order model based on four first-order factors. The results showed that the second-order four-factor model demonstrated a better fit $\left(\chi^{2}=69.19\right.$, $\mathrm{df}=60, \mathrm{CFI}=0.98, \mathrm{TLI}=0.98, \mathrm{SRMR}=0.05, \mathrm{RMSEA}=0.03$ ) than the first-order onefactor model $\left(\Delta \chi^{2}=9.05, \Delta \mathrm{df}=3, p<0.05\right)$. Thus, the 13-item, second-order four-factor model of TFL was used as the independent variable for further analysis. Cronbach's $\alpha$ for the scale was 0.90 . Due to aggregating individual team members' ratings into team-level scores, ICC, $R_{\mathrm{wg}}$, and ANOVA were used to evaluate inter-rater reliability (James, 1982). The results suggested that the aggregations were justified (ICC (1) $=0.10$, ICC (2) $=0.33$, $\left.f=1.99 * * ; R_{\mathrm{wg}}=0.98\right)$ (George, 1990; James et al., 1984).

ISC. ISC was measured using the 18-item scale developed by Leana and Pil (2006). Specifically, a sample item for information sharing read: "TMT members engage in open and honest communication with each other"; a sample item for trust read: "TMT members have confidence in one another"; and a sample item for shared vision read: "Members of the TMT are committed to the goals of the company." The CFA results indicated a poor fit index for the original model $\left(\chi^{2}=428.21, \mathrm{df}=135, \mathrm{CFI}=0.78\right.$, $\mathrm{TLI}=0.75, \mathrm{SRMR}=0.08, \mathrm{RMSEA}=0.12$ ). After excluding three items with lower factor loadings[2], the first-order one-factor model of ISC shows a reasonable fit to the data $\left(\chi^{2}=253.64, \quad \mathrm{df}=90, \quad \mathrm{CFI}=0.85, \quad \mathrm{TLI}=0.83, \quad \mathrm{SRMR}=0.06, \quad \mathrm{RMSEA}=0.11\right)$. Furthermore, $\mathrm{CFA}$ was conducted to compare the first-order one-factor model of ISC with the second-order model based on three first-order factors. The results showed that the second-order, three-factor model demonstrated a better fit $\left(\chi^{2}=215.15, \mathrm{df}=87\right.$, $\mathrm{CFI}=0.89, \mathrm{TLI}=0.86, \mathrm{SRMR}=0.06, \mathrm{RMSEA}=0.10$ ) than the first-order, one-factor model $\left(\Delta \chi^{2}=38.49, \Delta \mathrm{df}=3, p<0.001\right)$. Therefore, the 15-item, second-order three-factor model of ISC was used for subsequent analysis. Cronbach's $\alpha$ for the scale was 0.93 .

ESC. Peng and Luo's (2000) six-item scale was used to measure ESC. CEOs judged the extent to which their TMT as a whole had frequent contacts with key personnel of external stakeholders (e.g. suppliers, customers, competitors, government, and agencies) during the past three years. The CFA results showed that the measurement model of ESC fit the data well $\left(\chi^{2}=26.51, \mathrm{df}=9, \mathrm{CFI}=0.96\right.$, $\mathrm{TLI}=0.93, \mathrm{SRMR}=0.04, \mathrm{RMSEA}=0.12)$ and all the factor loadings were between 0.59 and 0.85 . The RMSEA value of the model of ESC was higher than 0.08 , which is not generally exceeded in the literature (Landis et al., 2000). However, considering the relatively small sample size $(n=90)$, the measurement model was acceptable. Cronbach's $\alpha$ for the scale was 0.87 .

Organizational innovation. Organizational innovation was measured with a six-item scale originally developed by Miller and Friesen (1982), and later modified by Hoffman and Hegarty (1993). Finance managers were asked to report technological and managerial innovations in the past three years. A sample item read: "The rate of introduction of new products or services into the organization has grown rapidly in the past three years." The CFA results showed that the measurement model of 
LODJ

37,7

850

organizational innovation yields an acceptable fit to the data $\left(\chi^{2}=15.78, \mathrm{df}=8\right.$, $\mathrm{CFI}=0.98, \mathrm{TLI}=0.96, \mathrm{SRMR}=0.03, \mathrm{RMSEA}=0.08)$ and all the factor loadings were between 0.69 and 0.82 . Cronbach's $\alpha$ for the scale was 0.90 .

Control variables. At the individual level, CEO tenure was controlled because it may be related to innovation (Jung et al., 2008). CEO tenure was self-reported in years. Furthermore, TMT size was also controlled at the team level because it might influence TMT social capital as the outcome of members' collective socio-cognitions and dynamics (Collins and Clark, 2003). Team size was the number of executives on the team including the CEO. Finally, firm characteristics including age (number of years since founding) and size (logarithm of fulltime employees) were included as control variables at the firm level, because prior studies reported their positive relationship with innovation (Jung et al., 2008; Gumusluoglu and Ilsev, 2009). The natural log transform of firm size was used in the analyses.

\section{Results}

Measurement model test

CFA was performed by using individual-level data to test the construct distinctiveness of the four major variables of TFL, ISC, ESC, and organizational innovation. Considering the small sample size relative to the measurement items (Landis et al., 2000), item parcels were created to simplify the structural models. Specifically, the two items with the highest and lowest factor were combined loadings into one aggregated score, then the second highest and second lowest factor loading, and so on. With this method, 28 items were ultimately specified in a four-factor model (13 raw items for TFL; nine parcel items for ISC; three parcel items for ESC; and three parcel items for organizational innovation)[3]. The model yielded an acceptable fit index $\left(\chi^{2}=527.35\right.$, $\mathrm{df}=311, \mathrm{CFI}=0.94, \mathrm{TLI}=0.93, \mathrm{SRMR}=0.05, \mathrm{RMSEA}=0.06)$. All path loadings from the latent constructs were significant, confirming their convergent validity.

\section{Descriptive statistics}

Table I includes means, standard deviations, reliability coefficients, and correlations among all variables in this study. Inter-correlations showed that organizational innovation significantly and positively correlated with TFL $(r=0.21, p<0.01), \operatorname{ISC}(r=0.64, p<0.01)$, and ESC $(r=0.41, p<0.01)$. TFL had significant positive correlations with $\operatorname{ISC}(r=0.22$, $p<0.01)$ and $\operatorname{ESC}(r=0.19, p<0.01)$.

\begin{tabular}{lccccccccc}
\hline & Mean & SD & 1 & 2 & 3 & 4 & 5 & 6 & 7 \\
\hline 1. Transformational & & & & & & & & & \\
$\quad$ leadership & 4.81 & 0.59 & $(0.90)$ & & & & & \\
2. Internal social capital & 5.05 & 0.59 & $0.22^{* *}$ & $(0.93)$ & & & & & \\
3. External social capital & 3.72 & 0.96 & $0.19^{* *}$ & $0.17^{*}$ & $(0.87)$ & & & & \\
4. Organizational innovation & 4.88 & 0.88 & $0.21^{* *}$ & $0.64^{* *}$ & $0.41^{* *}$ & $(0.90)$ & & & \\
5. CEO tenure & 8.62 & 6.39 & 0.07 & 0.06 & 0.10 & -0.07 & & & \\
6. TMT size & 5.25 & 2.39 & -0.02 & $-0.33^{* *}$ & 0.05 & -0.10 & $0.20^{* *}$ & & \\
7. Firm age & 8.18 & 3.15 & 0.07 & -0.07 & 0.12 & -0.04 & $0.52^{* *}$ & 0.10 & \\
8. Firm size & 8.63 & 0.45 & 0.05 & -0.12 & 0.01 & $-0.17^{*}$ & $0.40^{* *}$ & $0.40^{* *}$ & $0.50^{* *}$
\end{tabular}

Table I.
Means, standard deviations, and correlations
Notes: $n=90$. Values on the diagonal (in parentheses) represent Cronbach's $\alpha . *_{p}<0.05 ; * * p<0.01$ (two-tailed) 
Bootstrapping analyses in Mplus 7.0 (Muthén and Muthén, 1998-2011) were conducted to test the hypotheses. All four control variables (i.e. firm age, firm size, TMT size, and CEO tenure) were included in the model. Figure 1 shows that the standardized path coefficients from TFL to ISC $(\beta=0.29, p<0.01)$ and TFL to $\operatorname{ESC}(\beta=0.28, p<0.01)$ are significant and positive. The results thus supported $H 1 a$ and $H 1 b$.

Table II shows the estimates of mediating effects of ISC and ESC. For ISC, both the stage 1 effect (TFL $\rightarrow$ ISC) and the stage 2 effect $(\mathrm{ISC} \rightarrow \mathrm{OI})$ are significant and positive $(\beta=0.29, p<0.01, \beta=0.48, \quad p<0.01)$, and the indirect effect through ISC also is significant and positive $(\beta=0.14, p<0.01)$. H2a was supported. Similarly, for ESC, both the stage 1 effect (TFL $\rightarrow$ ESC) and the stage 2 effect $(\mathrm{ESC} \rightarrow \mathrm{OI}) \quad(\beta=0.28, p<0.01, \beta=0.34, p<0.01)$, and the indirect effect through ESC are all significant and positive $(\beta=0.09, p<0.05)$. $H 2 b$ was supported. As a supplementary analysis, we tested the difference between the mediating effects of ISC and ESC, but found no significant difference $(t=0.03, p=0.37)$.

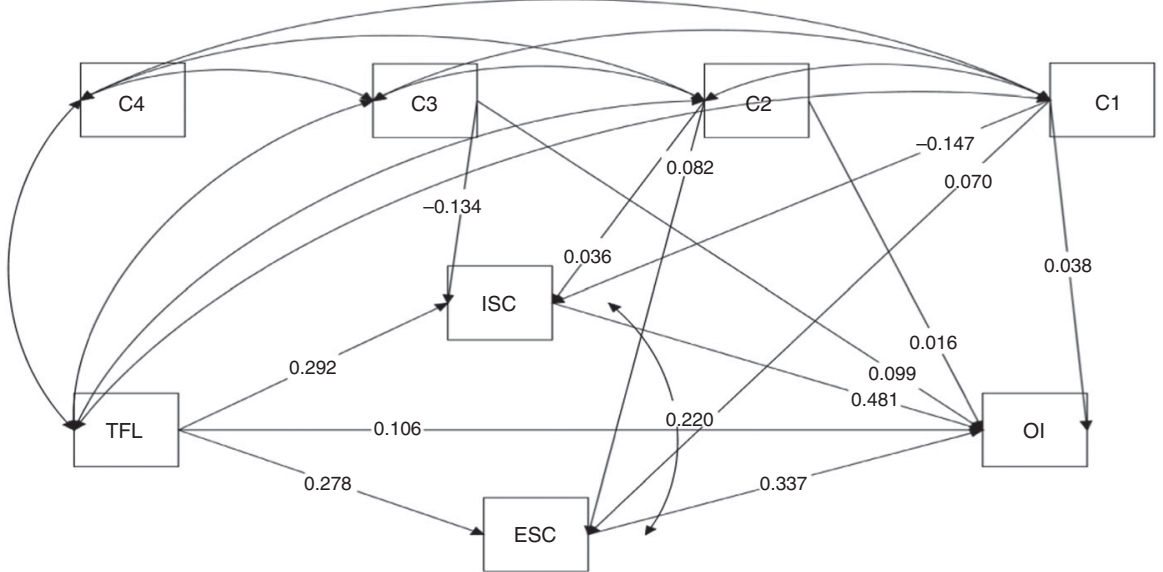

Notes: TFL, transformational leadership; ISC, internal social capital; ESC, external social capital; OI, organizational innovation; $\mathrm{C} 1$, CEO tenure; C2, TMT size; C3, firm age; $\mathrm{C} 4$, firm size

Testing $H 2 a$ : mediating role of internal social capital $\mathrm{TFL} \rightarrow \mathrm{ISC} \rightarrow$ OI

$\begin{array}{lll}0.29 * * * & 0.48^{* * * *} & 0.14 * \\ 0.28^{* * *} & 0.34^{* * * *} & 0.09 *\end{array}$

$\mathrm{TFL} \rightarrow \mathrm{ESC} \rightarrow \mathrm{OI}$

ship on organizational innovation through Notes: $n=90$. Indirect effects of transformational leadership on organizational inn
internal social capital and external social capital. $* p<0.05 ; * * p<0.01 ; * * p<0.001$ Table II. Mediating effects analyses

Standardized path loadings of the impact of transformational leadership on organizational innovation

Social capital and organizational innovation

851
Figure 1. 
LODJ

37,7

852

\section{Discussion}

\section{Theoretical implications}

This study makes several contributions to the literature. First, the leadership, social capital, and strategic management literatures are combined to propose and test a new perspective on how TFL influences innovation. In the broader TFL literature, Wang et al. (2011) called for further investigation of TFL mediators because of varying influences at individual, group, and organizational levels. TFLs' impact at the organizational level has been studied through individual and team processes and performance, as well as through organizational cultures, systems, and strategies (Liao and Chuang, 2007; Wang et al., 2011). This study features a different perspective pointing to relationships TMT members with one another and with outside stakeholders as inducing innovation. Researchers have previously focussed primarily on TFL's influence through human capital such as individual motivation and attitude or team identity, efficacy, and potency (e.g. Krishnan, 2012; Mason et al., 2014; Muchiri et al., 2012; Wang et al., 2011). We address this limitation by adding social capital to TFL influences. The findings strengthen the proposition that social capital (Burt, 1997) is behind human capital influences, especially in the case of TFL. In line with the proposition that both individual and social lenses are important in leadership research (Day, 2000), the findings of this study provide concrete evidence that social lenses can help us better decipher TFL as a mechanism impacting organizational outcomes.

The narrower base of literature on TFL and innovation has focussed on supportive climates and organizational policies (e.g. Gumusluoglu and Ilsev, 2009; Jung et al., 2008; Sarros et al., 2008). The findings support internal and external TMT social capital as a more proximal antecedent for transmitting TFL influence. Consequently, future researchers may want to consider both organizational-level antecedents and TMT-level antecedents, going beyond cognitive antecedents such as psychological empowerment and organizational climate to include social relational antecedents such as social capital.

Second, the present study extends TFL examinations beyond internal domains to external domains. Although TFL is known to have positive effects on internal informational and advice network structure (Bono and Anderson, 2005), few researchers have tested TFL effects outside organizations. The findings indicate that TFL influence spills over to the external domain through followers' external social relationships. These results respond to questions about TFL's adaptability and influence on the external environment (Makri and Scandura, 2010), and have significant implications for research exploring TFL impacts on organizational outcomes. Future research should look beyond organizational boundaries for a fuller account of TFL impacts. Furthermore, the findings suggest that TFL's positive impact on innovation is transmitted through ESC, above and beyond that transmitted through ISC. It has been relatively well-established that ISC mediates the positive influence of TFL on innovation, but the findings of the current study suggest that a focus on ISC is inadequate. ESC is complementary to ISC, highlighting that leaders must focus on both internal and external factors.

Third, social capital research has primarily focussed on its impacts on individual, group, and organizational outcomes, but has paid less attention to its antecedents (Shipilov and Danis, 2006). Although leadership has been shown to be a driving force behind ISC (Bono and Anderson, 2005; Carmeli et al., 2009), the direct relationship between leadership and ESC has been rarely examined. The findings of this study suggest that leadership is an important antecedent of both ISC and ESC. ISC and ESC serve different purposes but leadership influences both. More specifically, TFL can encourage internal cohesion and external ties. The findings point to the value of TFL 
behavior in terms of its social capital potential and offer empirical support for the proposition that TFL should be revisited in the light of its social capital contribution (Day, 2000). TFL should be added to the list of antecedents of social capital that warrant further exploration.

Social capital and

organizational innovation

Limitations and directions for future research

The findings must be understood in light of their limitations. In this field study, survey measures of TFL, social capital, and organizational innovation were collected concurrently. Although the data were collected from multiple sources including CEOs, TMT members, and finance managers to minimize same-source bias, it was impossible to prove causality between constructs. Future research should focus on collecting longitudinal data to test the relationships between TFL, social capital, and organization innovation.

In addition, the study was conducted in China, an emerging economy where executives' ESC is essential for accessing external resources and overcoming institutional, technological, and behavioral uncertainty (Peng and Luo, 2000). Companies in developed economies, however, rely much less on external ties (Zhao, 2015), so ESC may play a much smaller mediating role between CEO leadership and organizational innovation. Future research could replicate our study in other economies.

Finally, although this study went beyond other studies in using the social capital lens to examine potential mediators of the association between TFL and organizational innovation, some important variables remained unexplored ( $\mathrm{Ng}$ and Rieple, 2014). In particular, future research could consider potential mediators between TFL and TMT social capital such as boundary-spanning behaviors and strategic human resource management practices. Future studies should examine the mechanisms that mediate the relationship of TMT social capital and organization innovation such as team learning behaviors and team creativity.

\section{Managerial implications}

This study has several implications for managerial practices. First, to foster organizational innovation, transformational leaders should be placed in CEO roles, and both human and social capital must be leveraged. As the findings show, human capital and social capital are connected and should be equally considered for generating innovation.

Second and more important, appropriate social capital may further increase the effectiveness of a transformational CEO. Previous understandings have focussed on TFL effects on followers' knowledge and motivation. This study points out that transformational leaders can also influence follower-built relationships. If either TMT, ISC or ESC with outside actors experience setbacks, innovative performance may be negatively impacted despite the same level of TFL. Cultivating ISC and ESC helps clear the path from TFL to organizational innovation. To develop ISC, organizations must build trust, motivate information sharing, and strengthen a shared vision. To develop ESC, organizations must mobilize TMT members to establish and maintain strong ties with various external actors (Donate et al., 2015). Providing motivation, sharpening network building skills, and creating opportunities would be some effective approaches to help establish external managerial ties (Mccallum and O'Connell, 2009).

Third, ISC and ESC are both essential mediating paths. Organizations must monitor and cultivate both ISC and ESC for top level managers. If organizations hope to reap maximum innovative benefits from TFL, they must building an appropriate mix of internal and external social capital. 
LODJ

37,7

854

\section{Notes}

1. The three items excluded from the TFL measurement model are: the CEO specifies the importance of having a strong sense of purpose; the CEO treats others as individuals rather than just a member of a group; and the CEO suggests new ways of looking at how to complete assignments.

2. The three items excluded from the ISC measurement model are: members share and accept constructive criticisms without making it personal; members discuss personal issues if they accept job performance; and there is no "team spirit" among members in the TMT (reverse coded).

3. TFL was treated as a second-order four-factor model of which the four factors have three, four, four, and two raw items, respectively. ISC was treated as a second-order three-factor model of which the three factors have three, three, and three parcel items, respectively.

\section{References}

Adler, P.S. and Kwon, S.W. (2002), "Social capital: prospects for a new concept", Academy of Management Review, Vol. 27 No. 1, pp. 17-40.

Balkundi, P., Kilduff, M. and Harrison, D.A. (2011), "Centrality and charisma: comparing how leader networks and attributions affect team performance", Journal of Applied Psychology, Vol. 96 No. 6, pp. 1209-1222.

Barney, J. (1991), "Firm resources and sustained competitive advantage", Journal of Management, Vol. 17 No. 1, pp. 99-120.

Barney, J.B. (2001), "Is the resource-based theory a useful perspective for strategic management research? Yes", Academy of Management Review, Vol. 26 No. 1, pp. 41-56.

Bass, B.M. and Avolio, B.J. (1997), Full-Range of Leadership Development: Manual for the Multifactor Leadership Questionnaire, Mind Garden, Palo Alto, CA.

Birasnav, M., Rangnekar, S. and Dalpati, A. (2011), "Transformational leadership and human capital benefits: the role of knowledge management", Leadership \& Organization Development Journal, Vol. 32 No. 2, pp. 106-126.

Bono, J.E. and Anderson, M.H. (2005), "The advice and influence networks of transformational leaders", Journal of Applied Psychology, Vol. 90 No. 6, pp. 1306-1314.

Briona, S., Chauveta, V., Cholletb, B. and Mothe, C. (2012), "Project leaders as boundary spanners: relational antecedents and performance outcomes", International Journal of Project Management, Vol. 30 No. 6, pp. 708-722.

Burt, R.S. (1997), "The contingent value of social capital", Administrative Science Quarterly, Vol. 42 No. 2, pp. 339-365.

Carmeli, A., Gelbard, R. and Reiter-Palmon, R. (2013), "Leadership, creative problem solving capacity, and creative performance: the importance of knowledge sharing”, Human Resource Management, Vol. 52 No. 1, pp. 95-122.

Carmeli, A., Ben-Hador, B., Waldman, D. and Rupp, D. (2009), "How leaders cultivate social capital and nurture employee vigor: implications for job performance", Journal of Applied Psychology, Vol. 94 No. 6, pp. 1553-1561.

Carter, D.R., Dechurch, L.A., Braun, M.T. and Contractor, N.S. (2015), "Social network approaches to leadership: an integrative conceptual review", Journal of Applied Psychology, Vol. 100 No. 3, pp. 597-622.

Cho, J. and Dansereau, F. (2010), "Are transformational leaders fair? A multi-level study of transformational leadership, justice perceptions, and organizational citizenship behaviors", The Leadership Quarterly, Vol. 21 No. 3, pp. 409-421.

Coff, R.W. (1997), "Human assets and management dilemmas: coping with hazards on the road to resource-based theory", Academy of Management Review, Vol. 22 No. 2, pp. 374-402. 
Collins, C.J. and Clark, K.D. (2003), "Strategic human resource practices, top management team social network and firm performance: the role of human resource practices in creating organizational competitive advantage”, Academy of Management Journal, Vol. 46 No. 6, pp. 740-751.

Day, D.V. (2000), "Leadership development: a review in context", Leadership Quarterly, Vol. 11 No. 4, pp. 581-632.

Den Hartog, D.N. and Belschak, F.D. (2012), "When does transformational leadership enhance employee proactive behavior? The role of autonomy and role breadth self-efficacy", Journal of Applied Psychology, Vol. 97 No. 1, pp. 194-202.

Dess, G.G. and Sauerwald, S. (2014), "Creating value in organizations: the vital role of social capital”, Organizational Dynamics, Vol. 43 No. 1, pp. 1-8.

Donate, M.J., Peña, I. and Pablo, J.D.S.D. (2015), "HRM practices for human and social capital development: effects on innovation capabilities", The International Journal of Human Resource Management, Vol. 27 No. 9, pp. 1-26.

Eklinder-Frick, J., Eriksson, L.T. and Hallén, L. (2014), "Multidimensional social capital as a boost or a bar to innovativeness", Industrial Marketing Management, Vol. 43 No. 3, pp. 460-472.

Flynn, F.J. and Staw, B.M. (2004), "Lend me your wallets: the effect of charismatic leadership on external support for an organization”, Strategic Management Journal, Vol. 25 No. 4, pp. 309-330.

Galunic, C., Ertug, G. and Gargiulo, M. (2012), "The positive externalities of social capital: benefits from senior brokers", Academy of Management Journal, Vol. 55 No. 5, pp. 1213-1231.

García-Morales, V., Jiménez-Barrionuevo, M. and Leopoldo, G.Z. (2012), “Transformational leadership influence on organizational performance through organizational learning and innovation”, Journal of Business Research, Vol. 65 No. 7, pp. 1040-1050.

George, J.M. (1990), "Personality, affect, and behavior in groups", Journal of Applied Psychology, Vol. 75 No. 2, pp. 107-116.

Glaser, L., Fourné, S.P.L. and Elfring, T. (2015), "Achieving strategic renewal: The multi-level influences of top and middle managers' boundary-spanning”, Small Business Economics, Vol. 45 No. 2, pp. 1-23.

Gumusluoglu, L. and Ilsev, A. (2009), "Transformational leadership, creativity, and organizational innovation”, Journal of Business Research, Vol. 62 No. 4, pp. 461-473.

Gupta, V., Huang, R. and Yayla, A. (2011), "Social capital, collective transformational leadership, and performance: a resource-based view of self-managed teams", Journal of Managerial Issues, Vol. 23 No. 1, pp. 31-45.

Heavey, C., Mowday, R.T., Kelly, A. and Roche, F. (2009), "Reconceptualizing executive environmental scanning and search: implications for international leadership research and practice", Advances in Global Leadership, Vol. 5 No. 5, pp. 65-92.

Hitt, M. and Ireland, D.R. (2002), "The essence of strategic leadership: managing human and social capital", Journal of Leadership and Organizational Studies, Vol. 9 No. 1, pp. 3-14.

Hoffman, R.C. and Hegarty, H.W. (1993), "Top management influence on innovations: effects of executive characteristics and social culture”, Journal of Management, Vol. 19 No. 3, pp. 549-574.

Houghton, S., Smith, A. and Hood, J. (2009), "The influence of social capital on strategic choice: an examination of the effects of external and internal network relationships on strategic complexity", Journal of Business Research, Vol. 62 No. 12, pp. 1255-1261.

James, L.R. (1982), “Aggregation bias in estimates of perceptual agreement”, Journal of Applied Psychology, Vol. 67 No. 2, pp. 219-229.

James, L.R., Demaree, R.G. and Wolf, G. (1984), "Estimating within-group inter-rater reliability with and without response bias", Journal of Applied Psychology, Vol. 69 No. 1, pp. 85-89. 
LODJ 37,7

856
Jansen, J., George, G., Van Den Bosch, F. and Volberda, H. (2008), "Senior team attributes and organizational ambidexterity: the moderating role of transformational leadership", Journal of Management Studies, Vol. 45 No. 5, pp. 982-1007.

Jung, D., Wu, A. and Chow, C. (2008), "Towards understanding the direct and indirect effects of CEOs' transformational leadership on firm innovation", The Leadership Quarterly, Vol. 19 No. 5, pp. 582-594.

Kang, J.H., Solomon, G.T. and Choi, D.Y. (2015), "CEOs' leadership styles and managers' innovative behaviour: investigation of intervening effects in an entrepreneurial context", Journal of Management Studies, Vol. 52 No. 4, pp. 531-554.

Koka, B. and Prescott, J.E. (2002), "Strategic alliance as social capital: a multinational view", Strategic Management Journal, Vol. 23 No. 9, pp. 795-816.

Krishnan, V.R. (2012), "Transformational leadership and personal outcomes: empowerment as mediator", Leadership \& Organization Development Journal, Vol. 33 No. 6, pp. 550-563.

Landis, R.S., Beal, D.J. and Tesluk, P.E. (2000), “A comparison of approaches to forming composite measures in structural equation models", Organizational Research Methods, Vol. 3 No. 2, pp. 186-207.

Leana, C. and Pil, F. (2006), "Social capital and organizational performance: evidence from urban public schools", Organization Science, Vol. 13 No. 3, pp. 1-14.

Li, Q., Maggitti, P.G., Smith, K.G., Tesluk, P.E. and Katila, R. (2013), “Top management attention to innovation: the role of search selection and intensity in new product introductions", Academy of Management Journal, Vol. 56 No. 3, pp. 893-916.

Liao, H. and Chuang, A. (2007), "Transforming service employees and climate: a multilevel, multisource examination of transformational leadership in building long-term service relationships", Journal of Applied Psychology, Vol. 92 No. 4, pp. 1006-1019.

Lin, C. (2007), "Factors affecting innovation in logistics technologies for logistics service providers in China", Journal of Technology Management in China, Vol. 2 No. 1, pp. 22-37.

Makri, M. and Scandura, T.A. (2010), "Exploring the effects of creative CEO leadership on innovation in high-technology firms", The Leadership Quarterly, Vol. 21 No. 1, pp. 75-88.

Mason, C., Griffin, M. and Parker, S. (2014), "Transformational leadership development: connecting psychological and behavioral change", Leadership \& Organization Development Journal, Vol. 35 No. 3, pp. 174-194, doi: 10.1108/LODJ-05-2012-0063.

Mccallum, S. and O'Connell, D. (2009), "Social capital and leadership development: building stronger leadership through enhanced relational skills", Leadership \& Organization Development Journal, Vol. 30 No. 2, pp. 152-166.

Miller, D. and Friesen, P.H. (1982), "Innovation in conservative and entrepreneurial firms: two models of strategic momentum", Strategic Management Journal, Vol. 3 No. 1, pp. 1-25.

Muchiri, M.K., Cooksey, R.W. and Walumbwa, F.O. (2012), "Transformational and social processes of leadership as predictors of organizational outcomes", Leadership \& Organization Development Journal, Vol. 33 No. 33, pp. 662-683.

Mumford, M.D., Scott, G.M., Gaddis, B. and Strange, J.M. (2002), "Leading creative people: orchestrating expertise and relationships”, Leadership Quarterly, Vol. 13 No. 6, pp. 705-750.

Muthén, L.K. and Muthén, B.O. (1998/2010), Mplus User's Guide, Muthén \& Muthén, 6th ed., Los Angeles, CA.

Nahapiet, J. and Ghoshal, S. (1998), "Social capital, intellectual capital and the organizational advantage", Academy of Management Review, Vol. 23 No. 2, pp. 242-266.

Ng, W. and Rieple, A. (2014), "Special issue on 'The role of networks in entrepreneurial performance: new answers to old questions", International Entrepreneurship \& Management Journal, Vol. 10 No. 3, pp. 447-455. 
Nonaka, I. (1991), "The knowledge-creating company", Harvard Business Review, Vol. 69 No. 6, pp. 96-104.

A., Munshi, N. and Walumbwa, F.O. (2009), "The influence of leadership on innovation processes and activities”, Organizational Dynamics, Vol. 38 No. 1, pp. 64-72.

O'Reilly, C.A., Caldwell, D.F., Chatman, J.A., Lapiz, M. and Self, W. (2010), "How leadership matters: the effects of leaders' alignment on strategy implementation”, The Leadership Quarterly, Vol. 21 No. 1, pp. 104-113.

Peachey, J.W., Burton, L.J. and Wells, J.E. (2014), "Examining the influence of transformational leadership, organizational commitment, job embeddedness, and job search behaviors on turnover intentions in intercollegiate athletics", Leadership \& Organization Development Journal, Vol. 35 No. 8, pp. 740-755.

Pearce, C.L. and Ensley, M.D. (2004), "A reciprocal and longitudinal investigation of the innovation success process: the central role of shared vision in product and process innovation teams", Journal of Organizational Behavior, Vol. 25 No. 2, pp. 259-278.

Peng, M.W. and Luo, Y.D. (2000), "Managerial ties and firm performance in a transition economy: the nature of a micro-macro link", Academy of Management Journal, Vol. 43 No. 3, pp. 486-501.

Sanchez-Famoso, V., Maseda, A. and Iturralde, T. (2014), "The role of internal social capital in organizational innovation: an empirical study of family firms", European Management Journal, Vol. 32 No. 6, pp. 950-962.

Sarin, S. and McDermott, C. (2003), "The effect of team leader characteristics on learning knowledge application, and performance of cross-functional new product development teams”, Decision Sciences, Vol. 34 No. 4, pp. 707-739.

Sarros, J.C., Cooper, B.K. and Santora, J.C. (2008), "Building a climate for innovation through transformational leadership and organizational culture", Journal of Leadership \& Organizational Studies, Vol. 15 No. 2, pp. 145-158.

Sauer, N.C. and Kauffeld, S. (2015), "The ties of meeting leaders: a social network analysis", Psychology, Vol. 6 No. 4, pp. 415-434.

Schaubroeck, J., Lam, S. and Peng, A. (2011), "Cognition-based and affect-based trust as mediators of leader behavior influences on team performance", Journal of Applied Psychology, Vol. 96 No. 4, pp. 863-871.

Shipilov, A. and Danis, W. (2006), "TMG social capital, strategic choice and firm performance", European Management Journal, Vol. 24 No. 1, pp. 16-27.

Sparrowe, R.T. and Liden, R.C. (2005), "Two routes to influence: integrating leader- member exchange and social network perspectives”, Administrative Science Quarterly, Vol. 50 No. 4, pp. 505-535.

Sparrowe, R.T., Liden, R.C., Wayne, S.J. and Kraimer, M.L. (2001), "Social networks and the performance of individuals and groups", Academy of Management Journal, Vol. 44 No. 2, pp. 316-325.

Tjosvold, D., Yu, Z. and Wu, P. (2009), "Empowering individuals for team innovation in China: conflict management and problem solving", Negotiation and Conflict Management Research, Vol. 2 No. 2, pp. 185-205.

Tushman, M.L. and Murmann, J.P. (1998), "Dominant designs, technology cycles, and organizational outcomes", in Staw, B. and Cummings, L.L. (Eds), Research in Organizational Behavior, Vol. 20, JAI Press, pp. 213-266.

Wang, G., Oh, I.S., Courtright, S.H. and Colbert, A.E. (2011), "Transformational leadership and performance across criteria and levels: a meta-analytic review of 25 years of research", Group \& Organization Management, Vol. 36 No. 2, pp. 223-270.

Wright, P.M., Dunford, B.B. and Snell, S.A. (2001), "Human resources and the resource based view of the firm”, Journal of Management, Vol. 27 No. 6, pp. 701-721. 
LODJ 37,7

Zhao, H. (2015), "Are social ties always valuable to knowledge search? Contextualizing knowledge search by foreign subsidiary executives in an emerging economy", Management International Review, Vol. 55 No. 4, pp. 1-28.

Zhen, Z. and Peterson, S.J. (2011), "Advice networks in teams: the role of transformational leadership and members' core self-evaluations", Journal of Applied Psychology, Vol. 96 No. 5, pp. 1004-1017.

\section{Further reading}

Cheung, M.F.Y and Wong, C.S. (2011), "Transformational leadership, leader support, and employee creativity", Leadership \& Organization Development Journal, Vol. 32 No. 7, pp. 656-672.

\section{Appendix. The scales for the main variables}

\section{Transformational leadership}

(1) Our CEO talks about his/her most important values and beliefs.

(2) Our CEO considers the moral and ethical consequences of decisions.

(3) Our CEO emphasizes the importance of having a collective sense of mission.

(4) Our CEO spends time teaching and coaching.

(5) Our CEO considers an individual as having different needs, abilities, and aspirations from others.

(6) Our CEO helps others to develop their strengths.

(7) Our CEO talks optimistically about the future.

(8) Our CEO talks enthusiastically about what needs to be accomplished.

(9) Our CEO articulates a compelling vision of the future.

(10) Our CEO expresses confidence that goals will be achieved.

(11) Our CEO re-examines critical assumptions to question whether they are appropriate.

(12) Our CEO seeks differing perspectives when solving problems.

(13) Our CEO gets others to look at problems from many different angles.

\section{Internal social capital}

(1) TMT members engage in open and honest communication with each other.

(2) Members in the TMT have no hidden agendas or issues.

(3) Members willing share information with one another.

(4) Members in our TMT keep each other informed at all times.

(5) I can rely on the members I work with in the TMT.

(6) Members in the TMT are usually considerate of one another's feelings.

(7) Members have confidence in one another in the TMT.

(8) Members in the TMT show a great deal of integrity.

(9) Overall, members in the TMT are trustworthy.

(10) Members of the TMT share the same ambitions and vision for the company. 
(11) Members of the TMT enthusiastically pursue collective goals and mission.

(12) There is a commonality of purpose among members in the TMT.

(13) Members of the TMT are committed to the goals of the company.

(14) Members view themselves as partners in charting the company direction.

(15) Everyone is in total agreement on our company's vision

\section{External social capital}

(1) Members of the TMT have utilized personal ties, networks, and connections during the past three years with top managers at buyer firms.

(2) Members of the TMT have utilized personal ties, networks, and connections during the past three years with top managers at supplier firms.

(3) Members of the TMT have utilized personal ties, networks, and connections during the past three years with top managers at competitor firms.

(4) Members of the TMT have utilized personal ties, networks, and connections during the past three years with political leaders in various levels of the government.

(5) Members of the TMT have utilized personal ties, networks, and connections during the past three years with officials in industrial bureaus.

(6) Members of the TMT have utilized personal ties, networks, and connections during the past three years with officials in regulatory and supporting organizations such as tax bureaus, state banks, commercial administration bureaus, and the like.

\section{Organizational innovation}

(1) The rate of introduction of new products or services into the organization has grown rapidly.

(2) The rate of introduction of new methods of production or delivery of services into the organization has grown rapidly.

(3) The rate of introduction of new markets or market segments services into the organization has grown rapidly.

(4) The rate of introduction of new systems for strategic planning and control into the organization has grown rapidly.

(5) The rate of introduction of new systems for training, development or promoting managers into the organization has grown rapidly.

(6) The rate of introduction of new departments or managerial positions for improving intra-organizational coordination or other managerial practices that support product, market innovation has grown rapidly.

\section{Corresponding author}

Lu Chen can be contacted at: chenlu@uestc.edu.cn

For instructions on how to order reprints of this article, please visit our website: 